\title{
Practice and Exploration on Packaging Design Curriculum Construction and Teaching Reforms
}

\author{
Hua FENG \\ School of Liberal Arts, \\ Xi'an Siyuan University \\ Xi'an, China 710038 \\ fhua2010@163.com
}

\begin{abstract}
As a required course for undergraduate and vocational students related with network and new media majors, packaging design is a multi-disciplinary and practical course, which requires many years continuous education reforms from teaching methodology and curriculum development system aspects. To improve the teaching effect of curriculum both theoretically and practically, we have refined our teaching staff group, re-constructed teaching materials, produced several micro-videos on line courses, and made reforms on curriculum exam and evaluation system. These reforms enhanced students' actively learning interests and elevated their academic performance and thus obtained preliminary expected results. Therefore, we introduced some practical experiences and explorations on construction and curriculum design and teaching practice on traditional packaging design course education, and put forward some thoughts and useful suggestions on its application.
\end{abstract}

Keywords-Packaging Design; online course; professional education; education reform

\section{INTRODUCTION}

Packaging design is a strong theoretical and practical professional course required for network and new media major students. It mainly teaches the basic concepts of packaging design, fundamentals of consumption and motivation to consume goods packaging, brand marketing and packaging planning, and also contains lots of packaging design practice for many industries including cosmetics packaging design, chemical product packaging design, beverage product packaging design, food packaging design, as well as series of tourism product packaging design and etc. ${ }^{[1-3]}$.

With the rapid improvement of technology development, industrial evolution and social change, traditional education style are forced to reform and fit the new situation caused by leaping technological development. The previous in-classroom teaching model and contents were unable to meet the requirements of the current education ${ }^{[4]}$. Hence, we are obliged to reform and fit the new century education era.

In our latest reform of professional teaching program of packaging design course, we teach students focused on two aspects, one is traditional packaging decoration design, the other is goods packaging brand packaging design. And, packaging design course combining with the features new media and networks in our university, we updated our teaching materials, produced new micro-video lessons and teaching animations and etc. This paper express some practices and useful explorations in course construction and teaching reform of Packaging design during the past 5 years.

\section{TeAching Contents And StAFF TeAm Constructions}

\section{A. Teaching contents construction}

Textbooks are the first learning material for students to know the basic framework and feature of packaging course. So, we introduced two textbooks, one is planning textbooks in Chinese, the other is recommended textbooks in English, full of visual impact pictures and packaging brands and logos. These materials can fulfill the students' learning requirements basically.

Textbooks are always several years behind the technology and trend development, so, other than the recommend textbooks for students, our teaching groups work together and write a school book guide for professional packaging design training, which updated and added new contents nearly every year. Within the guide, we set 4-5 professional training sections, which directed by course instructor and train students to master the basic knowledge and ability.

Also, we updated the lecture courseware every year, add new contents including new design trend, hot packaging brand and planning style appreciation and latest exhibition news, which can be seen as table I. After years improvement, these teaching materials and lecture courseware formed a teaching system, including course learning outline, main parts, questions, homework, quiz and etc., so as to achieve full coverage of the main knowledge points. These efforts produced a good effect, both teachers and students benefit from the exploration and reforms. 
TABLE I. “PACKAGING DESIGN” COURSE KNOWLEDGE POINTS

\begin{tabular}{|c|c|c|}
\hline Chapter & Knowledge points & Sub knowledge points \\
\hline \multirow{2}{*}{ Packaging Design overview } & Definition of packaging design & Definition of Packaging design \\
\hline & Meaning of packaging design & Meaning of Packaging design \\
\hline \multirow{2}{*}{$\begin{array}{l}\text { Fundamentals of consumption and motivation to consume goods } \\
\text { packaging }\end{array}$} & $\begin{array}{c}\text { Packaging and decorating design , } \\
\text { workflow }\end{array}$ & $\begin{array}{l}\text { Packaging decorating design; Packaging design } \\
\text { workflow }\end{array}$ \\
\hline & Market research and data collection & $\begin{array}{l}\text { Market research; } \\
\text { Data collection }\end{array}$ \\
\hline \multirow{3}{*}{ Packaging and environment concerns } & Graphic design & LCA software \\
\hline & Material evaluation & 3R1D principle \\
\hline & Waste recycling & Carbon Emission \\
\hline \multirow{2}{*}{ Packaging brand planning and logo design } & Packaging brand plan & Packaging brand plan \\
\hline & Packaging logo design & Packaging logo Design \\
\hline \multirow{7}{*}{ Packaging design case study } & \multirow{2}{*}{ Cosmetics packaging design } & Mentadent" toothpaste packaging design \\
\hline & & marine mineral facial cleanser packaging design \\
\hline & \multirow{2}{*}{ Food packaging design } & Candy packaging design \\
\hline & & Tea packaging design \\
\hline & \multirow{2}{*}{$\begin{array}{c}\text { Series of tourism product packaging } \\
\text { design }\end{array}$} & Understand series of packaging design \\
\hline & & Local special packaging design \\
\hline & New goods pkg design, and etc. & New electronic goods packaging design, and etc \\
\hline
\end{tabular}

\section{B. Teaching group construction}

After more than 5 years of teaching group construction, packaging design curriculum has preliminarily build a teaching team which guided by an academic leader, contains two lecturers and one lab instructor, to meet the basic teaching requirement for undergraduate and vocational education in professional packaging and multi-level theoretical and practical teaching tasks. Also, we are very active engaged with international and domestic activities in recent years, we exchange with out-campus professional peer expert, and invite them to provide new design ideas and materials, invite them give lecture to our students talking about industries technology and design trend, and invite them to join as our part-time staffs if possible. They gave interesting lectures to students for new ideas and newly packaging events, like World Packaging Star competition, and appreciate the Gold, silver and bronze medal winning works, to analyze their development and design ideas, packaging material selection, and environmental concerns, as well as special packaging functions to consumer convenience. Through these efforts, we aimed to demonstrate students a general picture of packaging design and the future perspective of career favorite.

\section{Teaching ToOls and Teaching Methodology ReForm}

\section{A. The Application of Case Study Teaching Methodology}

Packaging design is a cross disciplines applied course that is strong related with goods image and brands construction. During the class, lots of case study on goods packaging design was introduced to the classroom, including cosmetics packaging design, chemical product packaging design, beverage product packaging design, food packaging design, as well as series of tourism product packaging design. Also, some top company's latest classic cases research works on cosmetics and beverage packaging were introduced into the teaching part, which not only enriched the classroom teaching contents and improved the whole education effect, but also make students have a growing interest and increase the sense of identity of the packaging professional. For example, lectures and training course on Orange juice packaging design, pharmaceutical packaging design, liquid detergent packaging design, as well as eggs packaging design, these case study process trained students have a good understanding of the specific application of the knowledge points and better knowing the future of course progress.

\section{B. The application of students-centered teaching method}

To build a student- centered study environment, a number of reforms and attempts have been made to achieve a good self-study and teaching effect on this course. There are a series regulation carried out to require both teachers and students to follow. Firstly, an online and offline internet based class was built to for teachers and students. Teachers are very convenient to upload teaching materials and download students' homework, manage quiz and exams. It is very helpful to communicate with students via the internet. Secondly, teachers are required to manage the whole process of study, including pre-class, in class and after-class. Also, students are required to prepare and learn the online materials in advance, to know next class contents in general. Thirdly, during the class, teachers are required to focus on "studentcentered" teaching, to well-prepared the teaching session and discussion session. Also, prepare some questions from simple to advanced level, to encourage a certain amount students to participate the class teaching process. Meanwhile, in some scenario, , students are required to divide to 5-8 groups to discuss, debate and interact with other group students and teachers in classroom. These classroom teaching reforms, aimed for students in different levels to master their conceptual understanding, basic knowledge and extensive ability training and provoke deep thinking with professional oriented.

\section{The application of research teaching methodology}

It is crucial to design a novel package when to develop a new product, especially for big companies. Packaging plays a more important role on product image shaping and business promotion. So, for this market requirement, we practice 
students to participate a real brand packaging design group, to make market investigation, to discuss with customers, to design series packaging brand, to consult and obtain real market response, then modify and refine packaging design solutions, and finally to achieved a optimized packaging design solution. One thing need to mention is that, these works should be done in groups; the number of students should be 3 to 5 person. After they finished all the process, they are required to exhibit their works in PPT slide presentation and make defense on the class. Students, teachers as well as some invited company experts can work together to help these group students make better. If some company is satisfied with the packaging design solution, they may get to agreement with the students group, and transfer of well-designed packaging patents. These measures are aimed to improve multiple parts' interests and formed a win-win situation.

\section{The application of new media and teaching technology}

With the rapid development of multimedia technology and information technology, teachers are forced to advance with the information age. We need to change our teaching methods and achieve a goal from "talking good" to "teaching good", so as to response to the lifelong education system. After many teaching researches, ask questions in classroom, we found that students are more likely to active learning short videos, pictures, sounds and many other new media. These new media based teaching materials are very welcome to students, so teachers have to learn these new teaching forms firstly. Then, use this new tool to produce micro-course and form a online course system. The practice, experience and explorations will be discussed in the following section.

\section{Curriculum Practice Teaching Reform}

\section{A. Class teaching reforms}

Traditionally, most of the teaching process is done in classrooms. To achieve a better self-study effect on packaging design course, we made some reform and set several class times for a certain class task. For example, encourage students in group to look up professional information from library, investigate a giving produce and evaluate it packaging brand, and discuss and design a new packaging, and etc. Also, if there is an international exhibition on high end or luxury good, we encourage students to pay a visit, to recognize the famous goods, brand and the function, image of the special packaging. After the visit of the exhibition, students are required to hand on a certain homework, to show what they have found, explain the special features of a certain good packaging , the functions of the packaging, and try to demonstrate how it is made, and meanwhile to find its environmental concerns. From, these training, students are easy to know the basic knowledge of packaging, to master how to select and design a packaging, and hence how to plan a packaging brand.

\section{B. Packaging design tool advanced training}

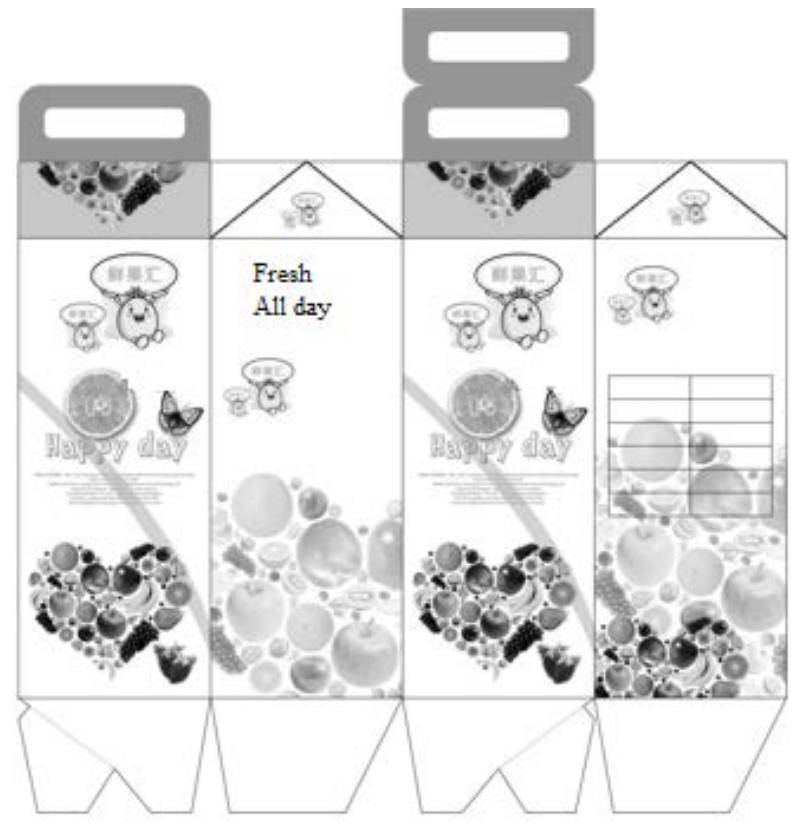

Fig. 1. A schematic diagram of packaging structure

To design a certain packaging brand and logo, students needs to use several packaging design tools to draw the inner packaging structure, out graphic image and create a prototype. Thus, they are required to use several important design software to finish a packaging design, including Illustrator CS, AI, Solid works, Photoshop CS, Artioscad, CAD, as well as 3D studio. To comprehensively use this software, is a strong ability as a certificated engineer. So, students are required and obliged to use software to design a given packaging structure and graphic text from simple to advanced level.

\section{Micro-video course design}

\section{1) PPT Design}

PPT is the most commonly used tool in micro-course teaching, and also the core content of micro-course production. There are several requirements of PPT design, which are as follows:

Teaching Scenario: Series Packaging Design
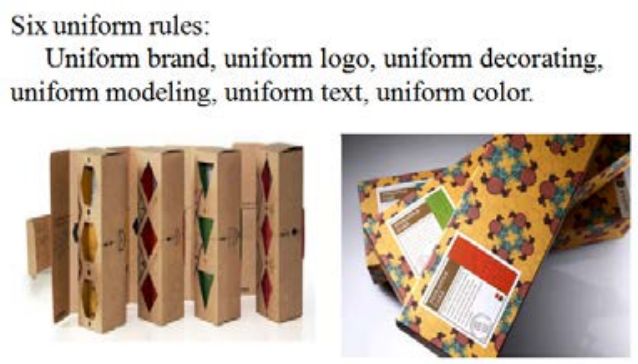

Fig. 2. PPT slide design sample

2) Micro-video design and produce

5-12 minutes short time video is very popular in modern age teaching. It is easier to understand than traditional pictures 
and texts ${ }^{[5,6]}$. For example, when students packaging design process, a micro video teach can be used to be show the whole process of how a brand packaging is designed and produced. How to control the process; manage the production precision and etc. Each process has corresponding text to explain, all the steps can be learn from the micro video, which is shown in Fig.3.

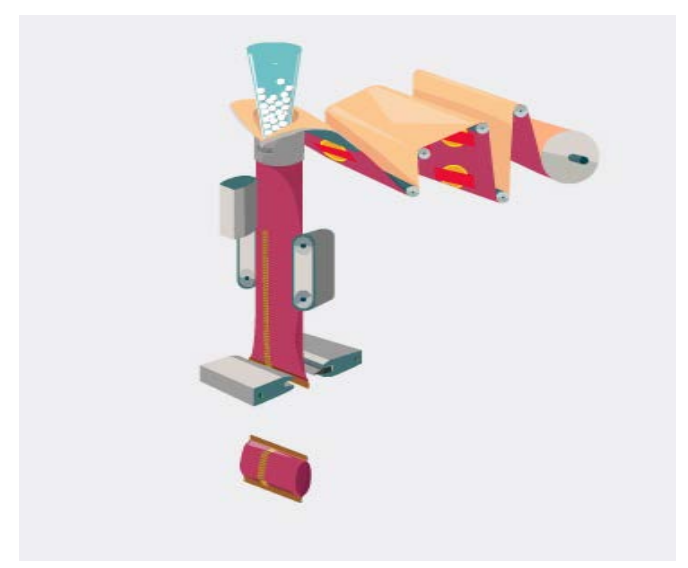

Fig. 3. A micro-video scenery

\section{Reform of curriculum assessment methods}

\section{1) Course assessment reform}

Packaging design is a curriculum that is rich in theory and practice, involving a number of theoretical hypothesis, consumer thinking and the corresponding production process. So, this course not only ranks the paper exams, but also pays more efforts on practice performance. This reform aimed to strengthen the flexible use of knowledge and professional tools. The examination scores of theoretical part accounted for $40 \%$, the others accounting for $60 \%$ which include the lab part, classroom attendance, homework, classroom performance and real case-study presentation performance. These reforms are used to encourage students participate in classroom discussions and check the real learning and teaching effect.

\section{2) Rating method reform}

During the scoring and rating process of the course, we are now planning to a certain free or exemption conditions for the outstanding students. For example, if the students passed the given packaging design engineer intermediate certification exam, or won the world packaging star completion, or won the first prize of the National University Students Packaging Design Competition, participate in other activities at the same level or above, these students could be granted the qualification of free examination, and the course scores are directly rated as "A" for encouraging students to pursue selfstudy and actively participate in course-related practice.

\section{CONCLUSIONS}

We are now emerging in a rapid development of new technology and new form of industry evolution, many types of specific market and novel brand produced and perished in a quick pace. As a teacher, we need to keep pace with the era, to learn new education methodology, to master teaching tools and ways firstly, and then apply the outcome to teach students. After several years curriculum and teaching reform on packaging design, we are happy to see that it achieved a better teaching and self-study effect. Technology revolution never stops the same situation to education. We demonstrated some practice and exploration in our university, and hope it is helpful to other courses and we will continuously make reforms on curriculum construction and teaching methods so as to advance with the time.

\section{ACKNOWLEDGMENT}

Thanks my student for their kind cooperation to this curriculum construction and teaching method reform. Also, they provide many case studies which contain many of their effective efforts. Also, the author wants to thanks these top packaging companies for their participation and support.

\section{REFERENCES}

[1] Wu Min, Wang Rui, Packaging Designer Must Read Manual[M],Beijing: Printing Industry Press, 2010. In chinese

[2] Tan Si Chao. Practical teaching and scientific research combined with innovative education model research [J]. Education Theory and Practice, 2007,27 (S1): 248-24.

[3] J Cheon, S Lee, SM Crooks, J Song, "An investigation of mobile learning readiness in higher education based on the theory of planned behavior," Computers \& Education, vol. 59, pp. 1054-1064, 2012.

[4] Yang Zubin, Dai Hongmin."New packaging solutions" new requirements for packaging personnel training [J].Packaging Engineering, 2009, 30 (9): 203-206.

[5] D. Juli, and C. Guorong, "Research and practice of 'micro-course' teaching mode," Journal of Chongqing University of Science and Technology (social sciences edition), vol. 9, pp. 153-155, 2014. In Chinese

[6] W. Juan, and C. Yao, "The new form of resources construction: the connotation and design framework of virtual simulation resources," China Educational Technology, vol. 12, pp. 91-96, 2016. In Chinese 